\title{
ЭКОЛОГО-ГИДРОХИМИЧЕСКИЕ ОСОБЕННОСТИ СОВРЕМЕННЫХ ТЕХНОГЕННЫХ ВОДОЕМОВ (НА ПРИМЕРЕ УРАЛЬСКОГО РЕГИОНА)
}

\author{
О. М. Гуман, А. Б. Макаров, И. А. Антонова, Г. Г. Хасанова \\ Уральский государственный горный университет, г. Екатеринбург
}

Поступила в редакцию 28 февраля 2018 г.

\begin{abstract}
Аннотация: работа посвящена исследованию компонентов современных техногенных водоемов, находящихся в пределах урбанизированных территорий и, в какой-то мере, оказывающих воздействие на природную окружающую среду. Образование подобных водоемов связано преимущественно с деятельностью предприятий различных отраслей промышленности и в настоящее время компоненты этих техногенных объектов активно взаимодействуют с природными. Изучено распределение тяжельх металлов в компонентах водоемов техногенного происхождения, приведены результаты сопряженного опробования снежного, ледового покрова, воды и донных отложений техногенных водоемов. Показаны возможности использования полученных данных для оценки их экологического состояния.
\end{abstract}

Ключевые слова: техногенез, техногенные водоемы, тяжелые металлы, оценка экологического состояния.

\section{ECOLOGICAL AND HYDROCHEMICAL FEATURES OF MODERN TECHNOGENIC WATER BODIES (ON THE EXAMPLE OF THE URAL REGION)}

\begin{abstract}
: this article deals with the study of the components of modern technogenic water bodies located within the urban areas and to some extent having an impact on the natural environment. The formation of such water bodies is mainly associated with the activity of enterprises of various industries, and nowadays the components of these man-made objects actively interact with natural resources. The authors studied the distribution of heavy metals in the components of technogenic water bodies. The results of the combined testing of snow cover, ice cover, water and bottom sediments of technogenic water bodies are presented. The possibilities to use the obtained data for assessing the ecological state are shown.
\end{abstract}

Key words: technogenesis, technogenic water bodies, heavy metals, assessment of the ecological state.

Эколого-геологические проблемы урбанизированных территорий являются в настоящее время весьма актуальными. Одной из таких проблем представляется наличие в городских агломерациях техногенных водоемов, которые являются элементом нарушенных земель, подлежащих рекультивации. С другой стороны компоненты этих водоемов могут быть использованы для оценки состояния окружающей среды $[1,2]$.

Формирование подобных объектов в пределах Уральского региона связано с деятельностью многочисленных промышленных предприятий, преимущественно горного и металлургического производства, а также добычей строительных материалов. При этом сформировавшиеся техногенные системы и объекты активно взаимодействуют с природными, что определяет переход многих химических элементов в подвижное состояние и их последующую миграцию, обусловленную воздействием на вещественные компоненты систем поступающих природных водных растворов различного состава и изменением кислотно-щелочных свойств среды. К категории техногенных водоемов можно отнести затопленные карьеры, пруды-шламоотстойники горнорудных предприятий (медные рудники Нижнего Тагила, Ельчевский шламоотстойник Дегтярского рудоуправления), обогатительных фабрик черной (шламонакопители Гороблагодатского и Первоуральского рудоуправления, Высокогорского и Качканарского горно-обогатительных комбинатов) и цветной металлургии (хвостохранилища Турьинской, Среднеуральской, Красноуральской, Кировградской, Пышминской, Бурибаевской и других обогатительных фабрик), металлургического производства (Металлургический завод им. А. К. Серова, Челябинский электрометаллургический комбинат), машиностроительных заводов (Первоуральский новотрубный завод) и многих других производств.

Формирование техногенных водоемов происходит различными способами, определяющими и закономерности их пространственного размещения. Водоемы в карьерных выемках распространены как в пределах горнодобывающих районов, так и непосредственно в городских агломерациях, в том числе и в 
г. Екатеринбурге. Так, в пределах территории г. Екатеринбурга искусственные водоемы в основном формировались в результате затопления выемок карьеров по добыче строительных материалов (Шувакишское и Уктусское месторождения глин, Сибирский каменный карьер) и грунтов для дорожного строительства, реже добычи других полезных ископаемых.

В пределах подобных водоемов, являющихся частью геотехнической системы (по Э.Ф. Емлину [3]), протекают сложные физико-химические процессы миграции и трансформации естественных и антропогенных компонентов в различных средах геосферы и техносферы. Особенности накопления тяжелых металлов определяются, в том числе расположением подобных водоемов в пределах открытых гидрогеологических структур, неровностях рельефа, часто заболоченных, циркументах [4].

Затопление карьерных выемок и появление искусственных водоемов происходит преимущественно за счет атмосферных осадков при участии в некоторых случаях и подземных вод. Водоемы небольших карьеров строительных материалов характеризуются новообразованными экосистемами пресноводных водоемов с формированием донных отложений. В накапливающихся донных отложениях современных водоемов в глинистой составляющей преобладают монтмориллонит, реже - каолинит и иллит [5]. Аналогичные образования характерны и для техногенных водоемов.

Сезонные изменения состава преимущественно кислых техногенных вод выражаются в колебаниях уровня водородного показателя за счет их разбавления атмосферными осадками, а в связи с повышением уровня рН отмечается общая тенденция к снижению концентрации металлов в воде. Это обусловлено тем, что при повышении рН в осадок, прежде всего, выпадают гидрооксиды железа и алюминия, которые по механизму поверхностной сорбции аккумулируют другие металлы. Поэтому в связи с повышением водородного показателя изменяется процентное соотношение металлов, мигрирующих во взвешенной и растворенной форме. Так, для поверхностных вотодотоков Бакальской ГТС К. А. Филипповой по результатам мониторинга [6] установлено, что в сильнокислых водах $(\mathrm{pH}<3)$ практически все железо находилось в растворенной форме, при $\mathrm{pH}=5,61$ доля взвешенной формы для железа составила 99,24 \%, что объясняется выпадением гидрооксидов железа из раствора при смене водородного показателя в зависимости от температуры, концентрации раствора и других параметров.

Подобные процессы характерны как для карьерных озер, так и для других замкнутых техногенных систем и объектов. По мере разбавления кислых промышленных вод атмосферными осадками и поверхностными водами уровень щелочного показателя увеличивается и возникает щелочной геохимический барьер. В процессе гидролиза в осадок выпадают гидроксиды железа (pH выпадения 3,8-4,5), алюминия (рН выпадения 4,1-5,0), которые обладают высокой сорбционной способностью для других металлов ( $\mathrm{Cu}, \mathrm{Zn}, \mathrm{Co}, \mathrm{Ni}, \mathrm{Pb}, \mathrm{Cd}$ и др.). При попадании подобных растворов в поверхностные воды (оз. Ключи, городской пруд г. Екатеринбурга) в условиях наличия слабого сероводородного заражения начинают формироваться отдельные хорошо окристаллизованные зерна пирита.

Наибольший интерес для исследования загрязнения и оценки экологического состояния подобных водоемов представляют донные отложения, которые, как известно, являются хорошим сорбентом органических веществ и на поверхности которых происходят активные биологические процессы [4]. Поступление тяжелых металлов определяется, в первую очередь, плоскостным смывом вещества с прилегающих территорий, нередко поступлением промышленных стоков предприятий, а также их аэрозольными выбросами и осадками с последующей адсорбцией тяжелых металлов на поверхности взвешенных иловых частиц и их седиментацией.

Весьма своеобразными техногенными водоемами являются пруды-отстойники и шламонакопители горнорудных предприятий. Пруды-отстойники предназначаются для улавливания взвешенного материала, поступающего с дренажными водами, и раскисления рудничных вод. Так, для бывшего рудника им. III Интернационала (г. Нижний Тагил) улавливание взвешенного материала, поступающего с дренажными водами, производилось на р. Ольховка каскадом из двух проточных прудков-накопителей и одного изолированного отстойника [7]. Верхний пруд-накопитель на р. Ольховка занимает площадь 1,8 га при объеме шламов 13 тыс м³ , з значительных концентрациях здесь присутствуют $\mathrm{Cu}, \mathrm{Zn}, \mathrm{Pb}, \mathrm{Hg}$.

Рудничные и сточные воды Дегтярского рудоуправления поступали в Ельчевский шламоотстойник, где сформировалась залежь техногенных илов объемом 3836,9 тыс. м ${ }^{3}$, содержание тяжелых металлов (\% масс.): $\mathrm{Cu}-1,14 ; \mathrm{Zn}-5,57 ; \mathrm{Ag}-1,6$ г/т.

Более значительными по масштабам являются прудки-осветлители шламов и обогатительных фабрик, занимающие периферические части хвостохранилищ черной металлургии. Накапливающиеся в них воды имеют значительные концентрации взвешенных веществ и тяжелых металлов [8]. Содержания тяжелых металлов в водах шламонакопителей некоторых металлургических предприятий приведены в табл. 1. Отметим высокие концентрации сульфат-иона и взвешенных веществ.

Геохимические особенности шламов здесь в целом определяются особенностями перерабатываемых руд, то же может относиться и к тяжелым металлам в водах шламоотстойников.

В шламохранилищах цветной металлургии и машиностроительных заводов состав тяжелых металлов определяется производственными процессами, а минеральный и химический состав отложений в целом 
Таблица 1

Концентрации тяжелых металлов в водах шламоотстойников, г/дм ${ }^{3}$

\begin{tabular}{|l|c|c|c|c|c|c|}
\hline \multicolumn{1}{|c|}{ Наименование объекта } & $\mathrm{Fe}$ & $\mathrm{Cu}$ & $\mathrm{Zn}$ & $\mathrm{SO}_{4}{ }^{2-}$ & Сухой остаток & $\mathrm{pH}$ \\
\hline Металлургический завод им. А. К. Серова: & & & & & & \\
1. Отстойник шламов нейтрализации & 0,43 & 0,016 & 0,26 & 1869,0 & 2671,6 & 7,9 \\
2. Отстойник №2 доменной пыли & 0,25 & 0,031 & 0,029 & 1057,6 & 1888,8 & \\
\hline Шламонакопитель РММЗ (по [9]) & 244,0 & 3,7 & 3,85 & 1620,0 & 2,4 & 2,9 \\
\hline Шламохранилище НТМК & 1,5 & 0,012 & 0,50 & 115,0 & 0,8 & 8,1 \\
\hline
\end{tabular}

формируется и при их последующих изменениях. В пределах хвостохранилищ Уральского региона эти процессы изучены пока недостаточно, однако известно, что в разрезе накопленных хвостов и шламов активно протекают процессы окислительного химического выветривания. Главный геохимический барьep приурочен здесь к горизонту исчезновения свободного кислорода и резкого возрастания $\mathrm{pH}$, что является главной причиной образования специфической минеральной корки (hardpan), содержащей гидрооксиды железа, ярозит, гипс и т.п. и препятствующей воздействию окисляющих и кислотных компонентов на нижележащие слои [10]. Не исключено, что изменения хвостов и шламов происходят и при участии гальмиролиза (подводное выветривание).

Наиболее активные процессы осаждения тяжелых металлов протекают в их краевых частях, на испарительном геохимическом барьере, где формируется сезонная минерализация. Так, в шламохранилище Бурибайской обогатительной фабрики в пределах этой зоны фиксируется образование кристаллических агрегатов гипса, в пределах шламоотстойника Уральского завода прецизионных сплавов, являющегося замкнутой системой (прямоугольная форма, образован насыпными дамбами, полиэтиленовый экран), они фиксируются в виде корочек на щебне известняка и алюминиевых шлаках. Отсыпка дамбы щебнем гранитов не создает геохимического барьера, на этом щебне осаждаются только гидроксиды железа. Сезонное осаждение сульфатов, учитывая кислый состав вод, при испарении в летний период определило формирование моренозита и гипса.

В условиях наличия значительного количества органической составляющей минералообразование протекает слабо, или его не происходит за счет поглощения металлов органикой. Вероятно, что мигрирующие тяжелые металлы встречают здесь другой вид геохимического барьера.

Изучение отложений шламоотстойников машиностроительных заводов показало их высокую насыщенность нефтепродуктами. Так, в шламоотстойнике Первоуральского новотрубного завода при отборе донных, существенно илистых, черных отложений, от них исходил запах нефтепродуктов, на поверхности фиксировались их плавающие пятна. Загрязнение донных отложений, по нашему мнению, связано с формированием в водонасыщенных осадках эмульсии. Вероятно, нефтепродукты гидрофобизируют поверхность глинистых иловых частиц, которые затем поступают в донные отложения. Монтмориллонит, преобладающий в составе донных отложений Урала, таким образом, способен сорбировать не только тяжелые металлы, но и органические загрязнители. Связь органического загрязнения и загрязнения тяжелыми металлами рассмотрена нами ранее [11].

На ряде участков нарушенных земель на территории МО г. Екатеринбурга сформировались водоемы техногенного происхождения, образованные за счет атмосферных осадков, поверхностных, подземных вод, а также в результате нарушения поверхностного стока [12].

Для оценки экологического состояния таких поверхностных водных объектов проводилось их гидрохимическое опробование и анализ состава поверхностных вод. Полный химический анализ воды включал определение $\mathrm{pH}$, окисляемости, гумуса, содержания хлоридов, сульфатов, нитратов, нитритов, ионов аммония, гидрокарбонатов, кальция, магния, натрия и калия, железа (общ) и величины сухого остатка, а также определялись взвешенные вещества, свинец, кадмий, мышьяк и нефтепродукты.

Обработка результатов опробования техногенных водоемов территории г. Екатеринбурга показала, что состав макро- и микрокомпонентов вод весьма разнообразен. В целом они характеризуются пестротой химического состава. Воды по преобладающим анионам и катионам, их количественному соотношению, в основном, пресные, гидрокарбонатные и смешанные, единичные пробы - хлоридные, сульфатные (рис. 1); по катионному - смешанные, единичные пробы - магниевые, кальциевые (рис. 2).

Воды карьеров преимущественно пресные с минерализацией до 0,8 г/л, реже воды соленые, с минерализацией воды 1,2-2,9 г/л.

Результаты гидрохимического опробования техногенных водоемов территории г. Екатеринбурга показали, что воды с повышенной минерализацией, с увеличением в их составе сульфатов, хлоридов, приурочены к заболоченным участкам, на которых часто наблюдаются несанкционированные свалки строительного, бытового мусора, либо к промышленным зонам.

Водоемы карьерных выемок, не нарушенные складированием в их пределах техногенных образований, имеют преимущественно сульфатно-гидрокарбонатный, хлоридно-гидрокарбонатный, реже гидрокарбонатный, сульфатно-хлоридно-гидрокарбонатный состав, по катионам - кальциево-магниевый, магниевокальциевый, минерализация воды изменяется от 77,1 до 467,7 мг/л. 


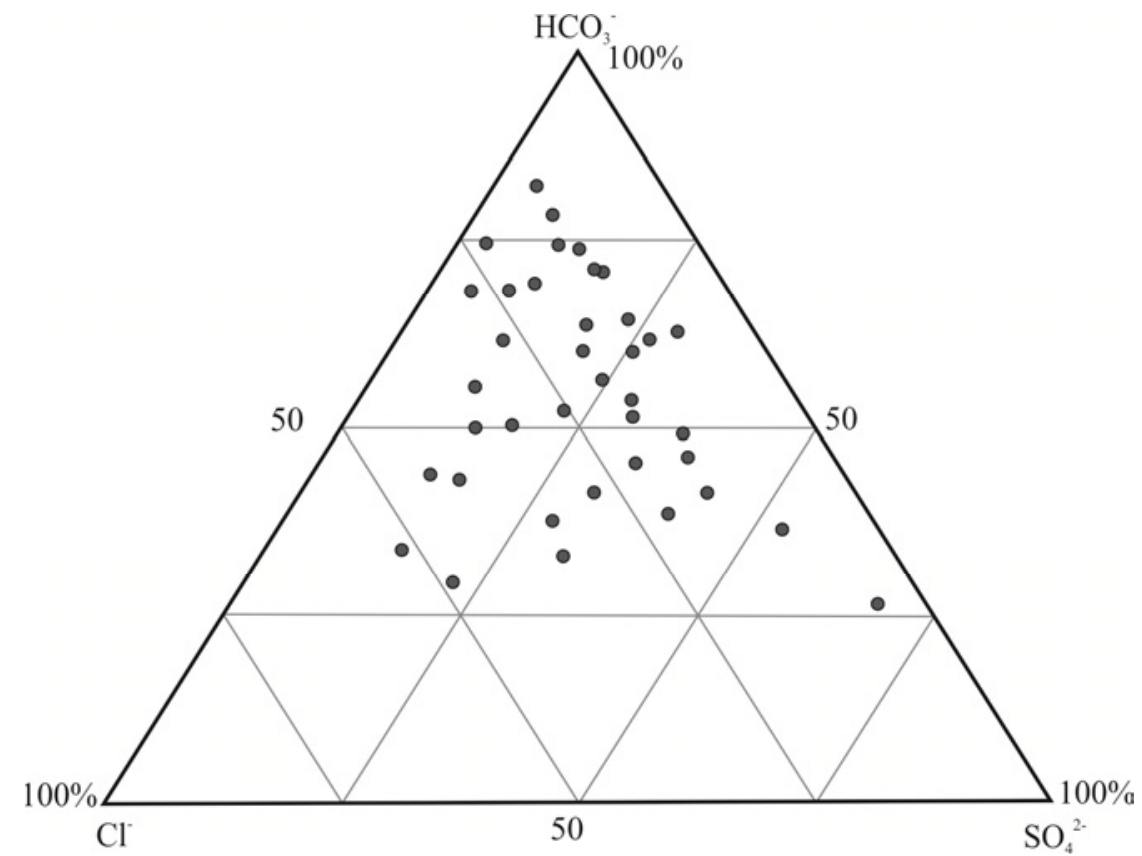

Puc. 1. Химический состав вод техногенных водоемов г. Екатеринбурга (анионы).

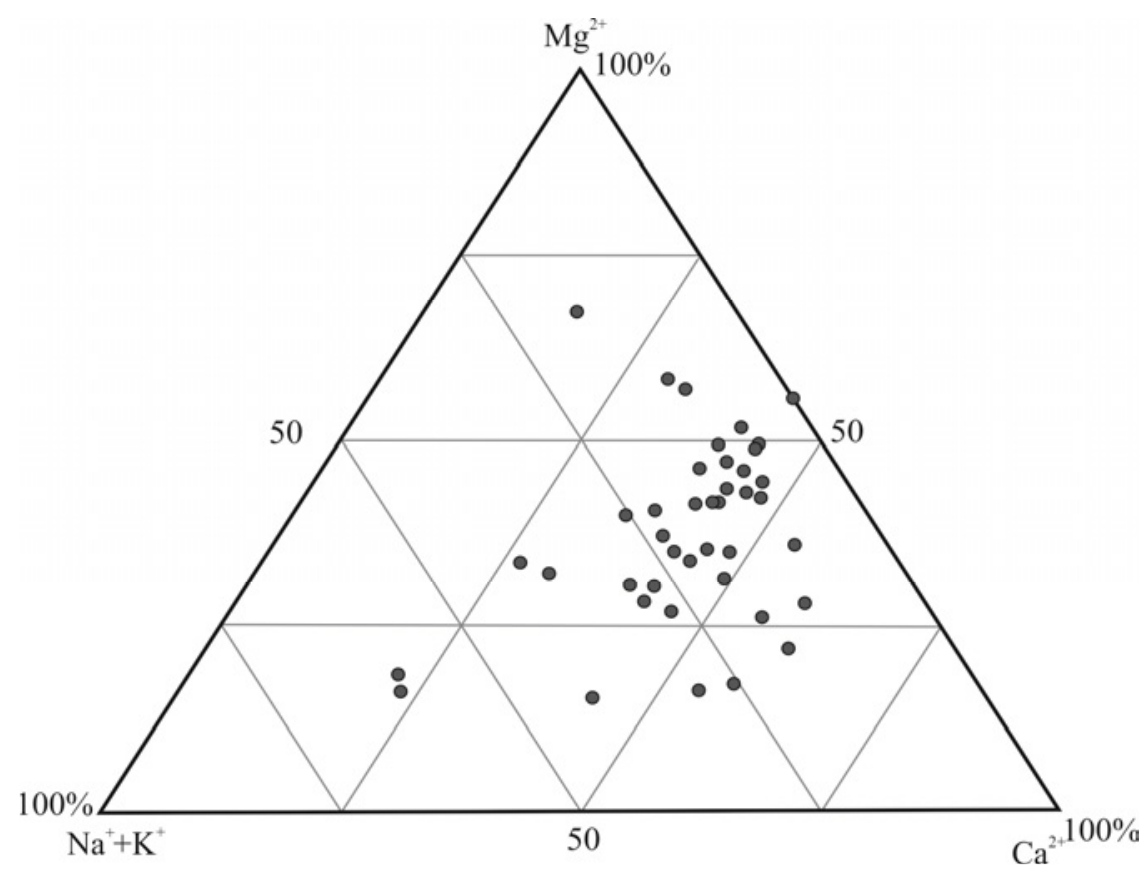

Puc. 2. Химический состав вод техногенных водоемов г. Екатеринбурга (катионы).

Результаты оценки экологического состояния вод техногенных водоемов на основе изучения ионносолевого состава и оценки содержания основных загрязняющих компонентов свидетельствуют о неблагополучной ситуации, сложившейся на территории ряда районов г. Екатеринбурга.

Поступление в атмосферу в результате производственной деятельности больших количеств различных элементов, в том числе металлов различных классов опасности, вызывает в последнее время все большую тревогу, поскольку, осаждаясь на дневную поверхность, они загрязняют почвы, растительность, водоемы.

С целью выявления источников загрязнения вод в зимних условиях выполнено сопряженное опробование снежного, ледового покровов и воды техногенных водоемов г. Екатеринбурга, расположенных по ул. Революции - Валовой, ул. Колхозников и вдоль Полевского тракта. Пробы снега отбирались в период начала весеннего таяния в городской черте методом «конверта» со стороной 1 м. Из углов и центра «конверта» отбиралось 5 равных по объему проб, которые смешивались на месте. Все пробы отбирали в полиэтиленовые мешки с замером площади и глубины 
пробоотбора. Пробы снежного покрова отбирались на всю мощность из шурфов. Размеры шурфа по длине и ширине изменялись от 0,25 до 0,5 м, на которую проектируются выпадения из атмосферы, мощность снега изменялась в пределах от 0,13 до 0,30 м. Пробы льда отбирались коловоротом в точках отбора снежного покрова. Пробы отбирали в полиэтиленовые мешки с замером диаметра и глубины отверстия. Мощность льда изменялась от 0,17 до 0,35 м, площадь лунки составляла $0,07 \mathrm{~m}^{2}$. Для таяния пробу на ночь помещали в пластиковый таз. Отстоявшуюся пробу фильтровали через бумажный фильтр с белой лентой. Фильтрат высушивали на воздухе и взвешивали. Вес осадка определяет общее количество пыли, выпадающей на единицу площади в единицу времени. Выпадение пыли определялось:

$$
P=\frac{P a}{S \cdot T},
$$

где $\mathrm{Pa} \mathrm{-} \mathrm{вес} \mathrm{пыли,} \mathrm{осажденной} \mathrm{снегом,} \mathrm{S} \mathrm{-}$ проективная площадь осаждения, $\mathrm{T}$ - временной интервал в сутках между моментом опробования территории и датой установления устойчивого снежного покрова. Всего проанализировано 8 проб снега, результаты приведены в табл. 2 .

Таблица 2

Пылевая нагрузка на исследуемые участки

\begin{tabular}{|c|c|c|c|c|c|}
\hline $\begin{array}{c}\text { Место водоема } \\
\text { опробования }\end{array}$ & $\begin{array}{c}\text { Вес } \\
\text { пыли, } \\
\text { мг }\end{array}$ & $\begin{array}{c}\text { Объем пробы } \\
\text { талого } \\
\text { снега, л }\end{array}$ & $\begin{array}{c}\text { Проективная } \\
\text { площадь } \\
\text { осаждения, м }\end{array}$ & $\begin{array}{c}\text { Временной } \\
\text { интервал, сут }\end{array}$ & $\begin{array}{c}\text { Пылевая } \\
\text { нагрузка, } \\
\text { мг/сут }{ }^{*} \text { м }^{2}\end{array}$ \\
\hline Революции - Валовой & 14,7 & 6,5 & 0,50 & 135 & 0,134018 \\
\hline Колхозников & 66,0 & 5,0 & 0,25 & 135 & 0,391111 \\
\hline Колхозников & 22,3 & 8,5 & 0,25 & 135 & 0,077734 \\
\hline Колхозников & 0,69 & 3,5 & 0,25 & 135 & 0,005841 \\
\hline Полевской тракт & 55,0 & 4,0 & 0,30 & 135 & 0,407407 \\
\hline Полевской тракт & 68,2 & 4,0 & 0,30 & 135 & 0,505185 \\
\hline Полевской тракт & 68,4 & 5,0 & 0,30 & 135 & 0,405333 \\
\hline Полевской тракт & 38,6 & 6,0 & 0,30 & 135 & 0,190617 \\
\hline
\end{tabular}

В пределах водоема в карьере, расположенном по ул. Колхозников, вертикальное опробование было выполнено в трех пунктах. В первом талые воды снежного покрова по макрокомпонентному составу относятся к хлоридно-гидрокарбонатным магниевокальциевым c минерализацией 43,5 мг/л, общей жесткостью 0,72 мг/экв. Количество взвешенных веществ в талой воде составляет 13,2 мг/л. По значениям водородного показателя рН воды нейтральные. Талые воды ледяного покрова по макрокомпонентному составу относятся к сульфатно-хлоридно-гидрокарбонатным натриево-магниево-кальциевым с минерализацией 48,0 мг/л, общей жесткостью 0,68 мг/экв. Количество взвешенных веществ в талой воде составляет 0,98 мг/л. По значениям водородного показателя $\mathrm{pH}$ воды нейтральные. Воды водоема по макрокомпонентному составу относятся к сульфатнохлоридно-гидрокарбонатным натриево-магниево-кальциевым с минерализацией 271,3 мг/л, общей жесткостью 3,85 мг/экв. Количество взвешенных веществ в воде составляет 22,7 мг/л, по значениям водородного показателя $\mathrm{pH}$ воды слабо основные.

Во втором пункте талые воды снега по макрокомпонентному составу относятся к хлоридно-сульфатно-гидрокарбонатным натриево-магниево-кальциевым с минерализацией 216 мг/л, общей жесткостью 2,73 мг/экв. Количество взвешенных веществ в талой воде составляет 2,6 мг/л, по значениям водородного показателя $\mathrm{pH}$ воды нейтральные. Воды льда по макрокомпонентному составу относятся к хлоридногидрокарбонатно-сульфатным натриево-магниево- кальциевым с минерализацией 212,1 мг/л, общей жесткостью 2,67 мг/экв. Количество взвешенных веществ в талой воде составляет 5,6 мг/л, по значениям $\mathrm{pH}$ воды нейтральные. Воды водоема по макрокомпонентному составу относятся к хлоридносульфатно-гидрокарбонатным натриево-магниевокальциевым с минерализацией 387,6 мг/л, общей жесткостью 5,61 мг/экв. Количество взвешенных веществ в воде составляет 18,3 мг/л, по значениям водородного показателя $\mathrm{pH}$ воды слабо основные.

В третьем пункте талые воды снежного покрова по макрокомпонентному составу относятся к хлоридносульфатно-гидрокарбонатным натриево-кальциевомагниевым с минерализацией 124,7 мг/л, общей жесткостью 1,96 мг/экв. Количество взвешенных веществ в талой воде составляет 0,2 мг/л. По значениям $\mathrm{pH}$ воды нейтральные. Талые воды льда по макрокомпонентному составу относятся к хлоридно-сульфатногидрокарбонатным натриево-кальциево-магниевым с минерализацией 203,4 мг/л, общей жесткостью 2,69 мг/экв. Количество взвешенных веществ талой воде составляет 9,44 мг/л. По значениям рН воды слабоосновные. Воды водоема по макрокомпонентному составу относятся к хлоридно-сульфатно-гидрокарбонатным натриево-магниево-кальциевым с минерализацией 425,1 мг/л, общей жесткостью 5,99 мг/экв. Количество взвешенных веществ в воде составляет 27,1 мг/л, по значениям рН воды слабоосновные.

Для оценки загрязнения тяжелыми металлами участка в целом были посчитаны их средневзвешенные значения в каждом слое (снег, лед, вода). В 
талой воде снега содержание $\mathrm{Ni}$ составляет 0,006 мг/л, $\mathrm{Cr}-0,022$ мг/л (2,2 ПДК), $\mathrm{Pb}-0,008$ мг/л, $\mathrm{Fe}-0,040$ мг/л. В талой воде льда содержание $\mathrm{Ni}$ на участке составляет 0,010 мг/л (1 ПДК), $\mathrm{Cr}-0,019$ мг/л $(1,9$ ПДК), $\mathrm{Pb}-0,013$ мг/л (1,3 ПДК), $\mathrm{Fe}-0,033$ мг/л. В водах водоема содержание $\mathrm{Ni}$ составляет 0,013 мг/л (1,3 ПДК), $\mathrm{Cr}-0,016$ мг/л (1,6 ПДК), $\mathrm{Pb}-0,013$ мг/л (1,3 ПДК), $\mathrm{Fe}-0,042$ мг/л.

На основе полученных данных были выявлены следующие закономерности: 1) увеличение с глубиной значений органолептических показателей, таких как водородный показатель $\mathrm{pH}$, количество гумуса, окисляемости, минерализации, общей жесткости; 2) увеличение с глубиной количества взвешенных веществ; 3) изменения в макрокомпонентном составе - увеличение с глубиной содержаний $\mathrm{Cl}^{-}, \mathrm{SO}_{4}^{-}, \mathrm{Na}^{+}$, уменьшение $\mathrm{Mg}$; 4) изменение микрокомпонентного состава - увеличение с глубиной средневзвешенного значения $\mathrm{Fe}, \mathrm{Pb}$ и $\mathrm{Ni}$, уменьшение $\mathrm{Cr}$.

По макрокомпонентному составу, минерализации, количеству взвешенных веществ пробы водоема, отобранные зимой не отличаются от проб, отобранных ранее в летний период. Содержание гумуса, концентрации $\mathrm{Fe}$ и $\mathrm{Pb}$ в летних пробах превышает в два раза значения зимних проб, значения окисляемости в летних пробах в два раза меньше. Значения концентраций $\mathrm{Ni}$ и $\mathrm{Cr}$ не зависят от сезонности опробования.

На основе полученных данных были выявлены следующие закономерности (рис 3,4$): 1$ ) увеличение с глубиной средневзвешенного значения концентрации $\mathrm{Mn}$; 2) постоянные концентрации для всех сред $\mathrm{Sb}$ и $\mathrm{P}$; 3) концентрации остальных элементов с глубиной уменьшаются.

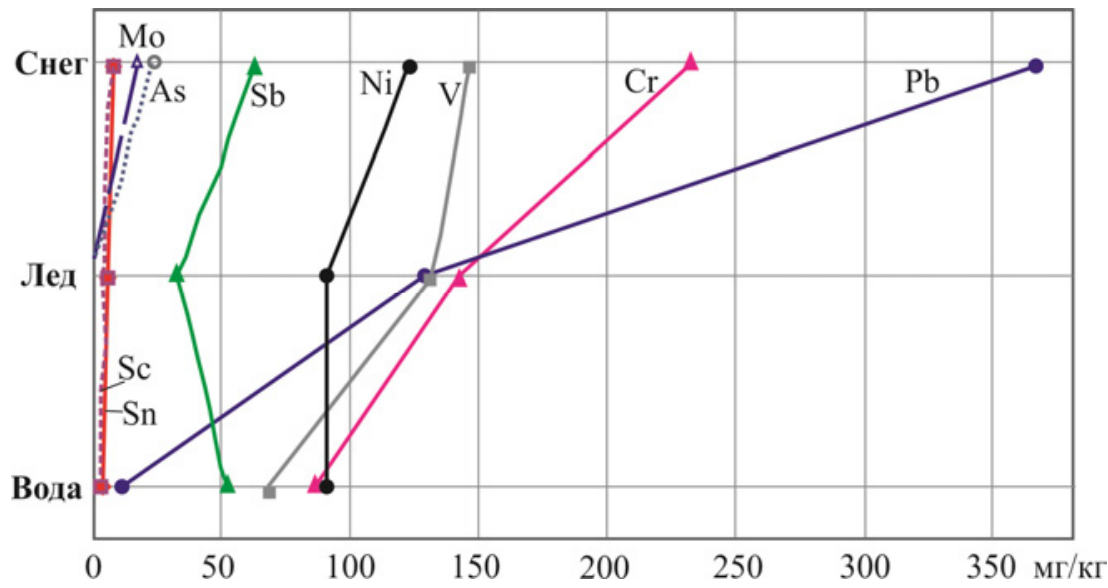

Puc. 3. Изменение концентраций химических элементов в твердой фазе (мг/кг) в осадках и водах техногенного водоема.

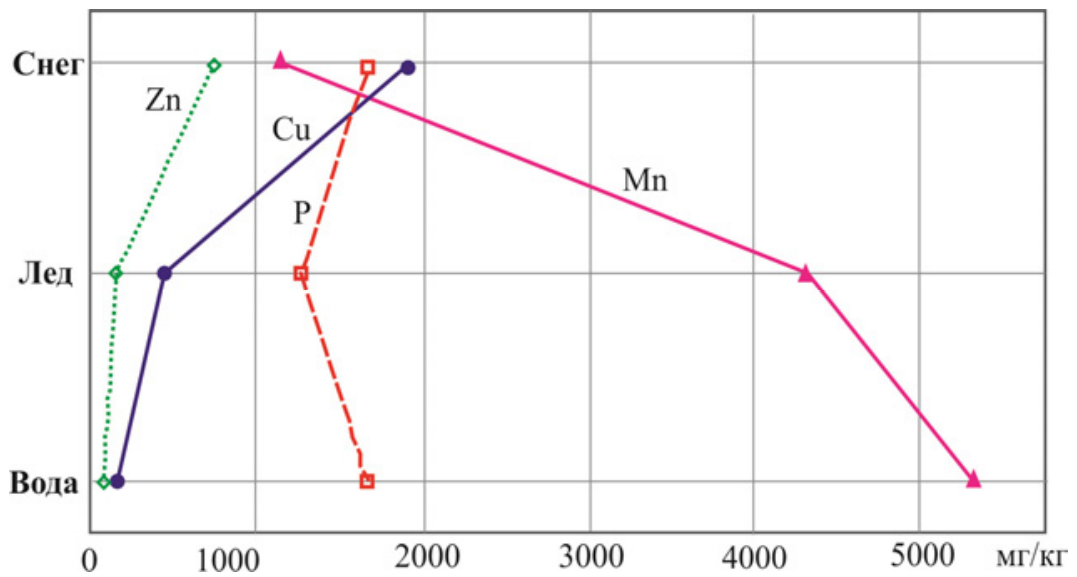

Puc. 4. Изменение концентраций химических элементов в твердой фазе (мг/кг) техногенного водоема.

Уменьшение концентраций тяжелых металлов в твердой фазе обусловлено их растворением, что объясняет рост концентрации этих же металлов в растворенной форме. Увеличение значений органолептических показателей обусловлено накоплением загрязнения с течением времени.

Отметим, что карьеры являются гидрогеологичес- кими «окнами», через которые происходит загрязнение подземных вод. Степень опасности таких участков определяется наличием в выемках промышленных, строительных или бытовых отходов и их объемами, глубиной залегания подземных вод, строением и мощностью зоны аэрации. Например, при складировании в отработанный карьер глин Горнощитский-V 
осадков городских сточных вод Южной аэрационной станции, характеризующийся относительно высокой защищенностью подземных вод, не наблюдается тенденций ухудшения качества подземных вод в наблюдательных скважинах вокруг карьера. Отсутствует микробиологическое загрязнение воды, окисляемость ниже предела чувствительности метода определения, концентрации основных компонентов загрязнителей, характерных для осадков городских сточных вод, находятся ниже предельно-допустимых, что свидетельствует об отсутствии или слабом влиянии на подземные воды.

При наличии в пределах выемок хорошо фильтрующих грунтов, малой мощности зоны аэрации, при наличии взаимосвязи между поверхностными и подземными водами в пределах выемок, происходит загрязнение подземных вод. Так, подземные воды в районе карьерной выемки, расположенной на юго-восточной окраине г. Екатеринбурга в пос. Кольцово, загрязнены по содержанию аммония, железа, свинца и кадмия.

\section{Выводы}

Анализ имеющихся материалов показывает многообразие процессов миграции и накопления тяжелых металлов в техногенных водоемах. Наиболее активно подобные процессы протекают в водоемах, связанных с хвостохранилищами и шламоотстойниками, нередко c формированием временной минерализации при активной роли органической составляющей. Наиболее близкими к природным водоемам, как по составу вод донных отложений, так и содержаниям в них тяжелых металлов, являются водоемы, сформировавшиеся в карьерах по добыче строительных материалов. В условиях накопления поступающих в эти водоемы тяжелых металлов возможно их использование для оценки экологического состояния территорий.

\section{ЛИТЕРАТУРА}

1. Косинова, И. И. Методические и правовые особенности проведения инженерно-экологических изысканий // И. И. Косинова, В. А. Бударина // Вестник Воронеж. гос. ун-та. Сер. Геология. - 2009. - № 1. - С. 164-166.

2. Современные антропогенные отложения и их использование для оценки экологического состояния ура- банизированных территорий / А. А. Селезнев [и др.] // Известия УГГУ. - Вып. 1 (45). - 2017. - С. 44-49.

3. Емлин, Э. Ф. Техногенез колчеданных месторождений Урала./ Э. Ф. Емлин // Свердловск: Изд-во Урал.ун-та; 1991. $-256 \mathrm{c}$.

4. Косинова, И. И. Литологический фактор как одна из причин неравномерности развития циркументов на территории Воронежской антеклизы// И. И. Косинова, В. В. Ильяш, Д. В. Ильяш // Вестник Воронеж. гос. ун-та. Сер. Геология. - 2013. - № 1. - С. 214-218.

5. Демчук, И. Г. Структурные особенности глинистых осадков современных водоемов / И. Г. Демчук, Ю. Б. Корнилов // Минералогия Урала. Т. 1. Научное издание. Миасс: Имин УрО РАН, 1998. - С.106-107.

6. Филиппова, $K$. А. Геохимия процессов техногенеза Бакальских железорудных месторождений (Южный Урал). Автореф. дисс. на соиск. уч. ст. к. г-м. н. Екатерин-бург, 2004. -23 c.

7. Макаров, А. Б. Тяжелые металлы в компонентах техногенных водоемов Уральского региона / А. Б. Макаров, И. А. Антонова, Г. Г. Хасанова // Вестник Уральского отделения Российского минералогического общества. Екатеринбург. 2017. - № 14. - C. 81-86.

8. Гуман, О. М. Геоэкологические условия района размещения шлакоотвала и отстойника-шламонакопителя Серовского металлургического завода / О. М. Гуман, И. А. Долинина, А. Б. Макаров // Известия УГГГА. Вып.15. Серия: Геология и геофизика.- 2002. - С. 263-272.

9. Копенкина, О. А. Оценка техногенного воздействия накопителей промышленных стоков металлургических предприятий Среднего Урала на подземные воды. Автореф. дисс. на соиск. уч. ст. к. г-м. н. Екатеринбург, 2008. -17 с.

10. Бортникова, С. Б. Геохимия и минералогия техногенных месторождений Салаирского ГОКа / С. Б. Бортникова, А. А. Айрнянц, Е. В. Колонин // Геохимия. - 1996. - № 2. C.171-185.

11. Долинина, И. А. Проблемы органического загрязнения промышленных территорий и их реабилитации / И. А. Долинина, О. М. Гуман, А. Б. Макаров // Современные проблемы науки и образования. -2012. - №4. - URL:www.scienceeducation.ru/104-6834 (дата обращения: 28.02.2018).

12. Макаров, А. Б. Минеральный состав и геохимические особенности донных отложений техногенных водоемов в юго-восточной части г. Екатеринбурга / А. Б. Макаров, И. С. Устюгова, А. В. Захаров // Проблемы минералогии, петрографии и металлогении. Научные чтения памяти П. Н. Чирвинского. - Вып. 13. Пермь, 2010. - С.316-321.

\section{The Ural State Mining University, Ekaterinburg}

Guman O. M., doctor of geological and mineralogical sciences, professor,

E-mail: Guman2007@mail.ru; Тел.: 8-904-380-33-42

Makarov A. B., doctor of geological and mineralogical sciences, professor,

E-mail: Guman2007@mail.ru; Тел.: 8-912-281-39-65

Antonova I. A., candidate of geological and mineralogical sciences, associate professor,

E-mail: dolinina_ira@mail.ru; Тел.: 8-929-224-86-68

Hasanova G. G., candidate of geological and mineralogical sciences, associate professor

E-mail: Gul_geol@mail.ru; Tел.: 8-904-988-62-09 